\title{
Respiratory symptoms and associated risk factors among under-five children in Northwest, Ethiopia: community based cross-sectional study
}

\author{
Zewudu Andualem, ${ }^{1}$ Asefa Adimasu Taddese, ${ }^{2}$ Zelalem Nigussie Azene, ${ }^{3}$ Jember Azanaw, ${ }^{1}$ Henok Dagne ${ }^{1}$ \\ ${ }^{1}$ Department of Environmental and Occupational Health and Safety, Institute of Public Health, College of Medicine and \\ Health Sciences, University of Gondar \\ ${ }^{2}$ Department of Epidemiology and Biostatistics, Institute of Public Health, College of Medicine and Health Sciences, \\ University of Gondar \\ ${ }^{3}$ Department of Women's and Family Health, School of Midwifery, College of Medicine and Health Sciences, University \\ of Gondar, Ethiopia
}

\begin{abstract}
Introduction: Acute respiratory infections are still a major public health problem resulting in morbidity and mortality among under-five children. This study aims to assess the extent of respiratory symptoms and associated risk factors among under-five children in Gondar city, Northwest Ethiopia.

Methods: A community-based cross-sectional study was carried out from February to June 2019. From 792 study participants, data were collected via face to face interviews by using a semi-structured pre-tested questionnaire. Data were entered in Epi Info version 7, then exported to Stata 14.00 for analysis. Binary (Bivariable and Multivariable) logistic regression analysis was used to test the association of explanatory and outcome variables. Variables with $\mathrm{p}<0.05$ were considered as significantly associated with the outcome variable.

Results: The prevalence of respiratory symptoms among under-five children was 37.5\% at [95\% (CI: 34.3-41)]. Uterine irritability during pregnancy [AOR $=1.89$ at 95\% CI: $(1.11-3.23)$ ], physical exercise during pregnancy [AOR $=0.60$ at $95 \%$ CI: (0.41-0.89)], using wood and coal for heating [AOR $=2.42$ at $95 \%$ CI: $(1.65-3.53)$ ], cockroaches infestation [AOR $=1.95$ at $95 \% \mathrm{CI}:(1.36-2.90)$ ], presence of new carpets [AOR $=2.38$ at $95 \%$ CI: (1.33-4.29)], damp stain $[\mathrm{AOR}=2.45$ at $95 \% \mathrm{CI}$ : $(1.02-2.69)$, opening windows during cooking $[\mathrm{AOR}=0.58$ at $95 \% \mathrm{CI}$ : $(0.36$ 0 .93)], living less than $100 \mathrm{~m}$ heavy traffic [AOR = 1.94 at 95\% CI: (1.16-3.27)], and living less than $100 \mathrm{~m}$ (unpaved roads/streets) $[\mathrm{AOR}=2.89$ at $95 \% \mathrm{CI}:(1.89-4.55)]$ were significantly associated with respiratory symptoms.

Conclusion: The prevalence of respiratory symptoms among under-five children was relatively high in the study area. Personal and environmental characteristics influencing symptom occurrence were identified. Respiratory symptoms will be minimized by reducing exposure to indoor and outdoor air pollution and enhancing housing quality.
\end{abstract}

Key words: Air pollution; respiratory symptoms; cross-sectional study; under-five children; Ethiopia.

Correspondence: Zewudu Andualem, Department of Environmental and Occupational Health and Safety, Institute of Public Health, College of Medicine and Health Sciences, University of Gondar, Ethiopia. E-mail: zewuduandualem12@gmail.com

Contributions: All stated authors were involved in the study from the inception to design, acquisition of data, analysis and interpretation, and drafting of the manuscript. All authors read and approved the final manuscript.

Conflict of interest: The authors declare that they have no competing interests.

Funding: The authors received no specific funding for this work.

Availability of data and materials: The dataset analyzed during the current study is available from the corresponding author upon reasonable request.

Ethics approval and consent to participate: The study was conducted after obtaining ethical clearance from the Institutional Review Board of University of Gondar with IRB number of (O/V/PRCS/05/369). An official letter of cooperation was written to Gondar city administration. After a clear and detailed explanation of the purpose, risks, and benefits of the study, written informed consent was obtained from each of the mothers/study participants. Mothers were told that participation was voluntary and that they could withdraw at any time if they were not comfortable during the interview. During data collection, under-five children identified with clear acute respiratory infection were referred to the health institutions for appropriate treatment. Personal identifiers were not included in the written tool to ensure confidentiality. The ethical statement was carried out in accordance with the principles of the Declaration of Helsinki.

Consent for publication: Not applicable. 


\section{Introduction}

Acute respiratory infections (ARI) are still a major public health problem resulting in morbidity and mortality among underfive children. Worldwide, it is estimated that about 7.6 million children died before celebrating their fifth year of birthday attributed to respiratory tract infections [1,2]. About more than half (i.e., $55 \%$ ) of deaths due to ARI symptoms are from 15 low and middleincome countries (LMICs) and nine of these countries are located in sub-Saharan African (SSA) region [3]. From an estimated, 5.4 million under-five children that died in 2017 roughly half of those deaths occurred in sub-Saharan Africa and ARIs contributed to the highest number of deaths [4].

Finding from Urban Slums of Gulbarga city found ARI incidence of $27.25 \%$ among under-five age group children [5]. A multi-country study conducted over sub-Saharan African countries has also reported the magnitude of acute lower respiratory infection (ALRI) for all the countries was 25.3\%, Congo (39.8\%), Gabon (38.1\%), Lesotho (35.2\%), and Tanzania (35.2\%) were the countries with the highest prevalence of ALRIs [6].

Indoor air pollution is one of the most important contributors to the global burden of disease, particularly in developing countries including Ethiopia, being children one of the most vulnerable groups [7]. The high incidence of ARI in children less than five years of age is one of the main reasons for pediatric outpatients' visits and hospitalization in developing countries [8]. Besides resulting in substantial morbidity and mortality, ARI also yields in multifaceted adverse consequences. Economic losses as a result of the use of healthcare resources, use of health personnel's time, disruption of the family, long time hospitalization and loss in productivity are some of them [9].

Ethiopia has made ample investments to reduce the burden of morbidity and mortality posed by ARI in the pediatrics segment of the population. Integrated management of common childhood illness and community case management are among the program initiatives scaled up nationally to address ARI in the country [10]. Previous studies have identified different factors linked with respiratory symptoms among children of under-five. Age and gender of the child, nutritional status, wealth index, parental educational status, large family size, exposure to biomass fuel, and parental smoking status, insufficient breastfeeding practice, poor immunization status, attendance to daycare centers, and overcrowding were important predictors of ARI among under-five children $[3,8,11,12]$.

This study aims to determine the extent of respiratory symptoms and associated risk factors among under-five children in Gondar city, Northwest Ethiopia.

\section{Methods}

\section{Study design, period, and area}

A community-based cross-sectional study was conducted from February 15, 2019, to June 20, 2019, in Gondar city, Northwest Ethiopia. The city is divided into 12 administrative areas (subcities) which consist of 21 kebeles (the smallest administrative units in Ethiopia). It has an estimated total population of 324, 000 with about 23,929 under-five children.

\section{Sample size calculation and sampling procedure}

The sample size was determined by using a single population proportion formula [13] considering the following assumptions: $p$ $=50 \%$ proportion of children with respiratory symptoms (there is no previous study in the study area), 95\% confidence interval, 5\% margin of error (d) and design effect 2

$$
\mathrm{n}=\frac{\left(\mathrm{Z}_{\frac{\alpha}{2}}\right)^{2} * \mathrm{P}(1-\mathrm{P})}{\mathrm{d}^{2}} \mathrm{n}=\frac{(1.96)^{2} * 0.5(1-0.5)}{(0.05)^{2}}=384
$$

Since we used multi-stage sampling technique, it demands us to use design effect of 2 and we used $5 \%$ non-response rate, thus, final sample size $(2 \times 384+768 \times 0.05)=806$.

Multi-stage sampling was used as an assumption of being a heterogeneous population in the 12 administrative areas of the cities. Fifty percent of total sub-cities were randomly selected from the 12 administrative areas and all eligible study participants present in the selected sub-cities were included in the study. Study participants were selected through simple random sampling technique.

\section{Data collection tools and procedures}

Through a face-to-face interview at the participants' home, data were collected using a pretested semi-structured questionnaire. The questionnaire was developed by reviewing different literatures [12,14-16]. The questionnaires include the outcome variable i.e. respiratory symptoms (such as cough, shortness of breath, wheezing, chest tightness, phlegm, and a problem in the chest including blocked, or running nose) and the explanatory variables: such as socio-demographic factors (age of a child, age of mothers, average monthly income, mothers and spouse educational level, etc.) and household air pollutants (such as type of fuels for cooking, types of fuel for heating, pesticide application, contact with farm animals (e.g. cattle, pigs, goats, sheep or poultry), smoke cigarettes (mothers/guardians), cockroach infestation in a household $(\mathrm{HH})$, painting/staining done in the last 6 months $\mathrm{HH}$, new carpets, drapes or other textiles in the last 6 months and using air fresheners, etc.) and house characteristics such as floor construction materials, wall surface water-based paint, ceiling surface, damp stains, visible mold, place of cooking, open doors during cooking, open windows during cooking, and time of spending indoors on an average day.

The questionnaire was first prepared in English and then translated to Amharic (local language) and back to English to maintain consistency of the tool. In the data collection process, six licentiate nurses and one BSc nurse were involved. Data collectors and supervisors have received two-days training.

\section{Operational definitions}

The outcome variable of this study was respiratory symptoms. Respiratory symptoms were defined in this study as to whether the children under-five years of age had been suffering from cough, shortness of breath, wheezing, chest tightness, phlegm, and a problem in the chest including blocked, or running nose $[17,18]$. Under-five children who have experienced at least one of the above-mentioned symptoms for the last 12 months prior to the study were considered as having respiratory symptoms.

\section{Data processing and analysis}

Data were first checked manually for completeness and then coded and entered into Epi Info version 7, then exported to Stata 14.00 for data checking, cleaning, and analysis. Descriptive statistics were performed to describe the study population with dependent and independent variables. Model fitness was checked with the assumptions of the Hosmer and Lemeshow goodness of fit test. $\mathrm{Bi}$-variable and multivariable logistics regressions were computed to identify the presence and strength of associations. Variables with a $\mathrm{p}<0.2[19]$ in the bivariable binary logistic regression analysis 
were included in the multivariable binary logistic regression analysis. Odds ratios with $95 \%$ CI were computed and variables having a $\mathrm{p}$ less than 0.05 in the multivariable binary logistic regression models were considered significantly associated with the dependent variable.

\section{Results}

\section{Socio-demographic characteristics of the study partici- pants}

A total of 806 study participants were aimed in this study. Out of these, 792 participants were enrolled with a response rate of $98.26 \%$. The median age of under-five children was 24 months \pm 12.24 (SD) and about $431(54.4 \%)$ were males. $28.65 \%$ of the study participants' mothers were in the age of $18-25$ years and $22.98 \%$ were above 33 years. The majority $(77.02 \%)$ of the study participants were Orthodox Christian by their religious affiliation (Table 1).

\section{Household air quality and housing characteristics}

Three-fifth (60.48\%) of the study participants reported the use of charcoal for cooking food. Only few $(2.15 \%)$ of fathers and
(3.03\%) of mothers smoked cigarettes and $47.85 \%$ of households were infested by cockroaches. Out of the study participants, 250 $(31.57 \%)$ have spent their time between 6 to $11 \mathrm{~h}, 179(31.57 \%)$ $>15 \mathrm{~h}$, and $198(25 \%)<6 \mathrm{~h}$ indoors in home, respectively. Above half $(55.56 \%)$ of the study participants used wood and coal for heating their house during humid weather condition and $43.06 \%$ did not use any fuel for heating (Table 2).

\section{Prevalence of respiratory symptoms among under-five children}

The prevalence of respiratory symptoms among under-five children in Gondar city was $37.5 \%$ at [95\% (CI: 34.3-41)]. The most common respiratory symptoms were runny nose $(25.63 \%)$, phlegm (10.48\%), and wheezing $(9.72 \%)$. The lowest reported respiratory symptom was chest tightness $3.03 \%$ (Figure 1).

\section{Factors associated with respiratory symptoms among under-five children}

In multivariable analyses, problems during pregnancy (e.g. hyperirritability of uterus), regular physical activity during pregnancy, the heredity of respiratory disease, fuel type usually used for heating, cockroach infestation in home, presence of new carpets, damp stains, opening windows during cooking, living less

Table 1. Socio-demographic characteristics of study participants in Gondar city, Northwest Ethiopia, 2019.

\begin{tabular}{|c|c|c|c|}
\hline Variables & & Frequency $(n=792)$ & $\%$ \\
\hline Sex of child & Female & 361 & 45.6 \\
\hline Age of child & $\begin{array}{l}12 \text { months } \\
13-24 \text { months } \\
25-36 \text { months } \\
37-48 \text { months } \\
49-59 \text { months } \\
\text { Median age of children } 24 \pm 12.24 \text { (SD) }\end{array}$ & $\begin{array}{l}204 \\
213 \\
181 \\
152 \\
42\end{array}$ & $\begin{array}{l}25.76 \\
26.89 \\
22.85 \\
19.19 \\
5.30\end{array}$ \\
\hline Education level of mothers & $\begin{array}{l}\text { Unable to read and write } \\
\text { Read and write } \\
\text { Primary } \\
\text { Secondary } \\
\text { Graduate from vocational } \\
\text { Diploma and above }\end{array}$ & $\begin{array}{c}121 \\
90 \\
100 \\
253 \\
30 \\
184\end{array}$ & $\begin{array}{c}15.55 \\
11.57 \\
12.85 \\
32.52 \\
3.86 \\
23.65\end{array}$ \\
\hline Age of mothers & $\begin{array}{l}\text { 18-25 years } \\
26 \text { - } 28 \text { years } \\
29-32 \text { years } \\
>33 \text { years } \\
\text { Median age of mothers } 28 \pm 5.86 \text { (SD) }\end{array}$ & $\begin{array}{l}227 \\
206 \\
177 \\
182\end{array}$ & $\begin{array}{l}28.66 \\
26.01 \\
22.35 \\
22.98\end{array}$ \\
\hline Religion & $\begin{array}{l}\text { Orthodox } \\
\text { Muslim } \\
\text { Others* }\end{array}$ & $\begin{array}{c}610 \\
140 \\
42\end{array}$ & $\begin{array}{c}77.02 \\
17.68 \\
5.30\end{array}$ \\
\hline Occupation of mother $(n=784)$ & $\begin{array}{l}\text { Housewife } \\
\text { Farmer } \\
\text { Student } \\
\text { Private employee } \\
\text { Government employee } \\
\text { Merchant } \\
\text { Others (specify) }\end{array}$ & $\begin{array}{c}533 \\
4 \\
8 \\
52 \\
142 \\
35 \\
10\end{array}$ & $\begin{array}{c}67.98 \\
0.51 \\
1.02 \\
6.63 \\
18.11 \\
4.46 \\
1.28\end{array}$ \\
\hline Occupation of father $(n=723)$ & $\begin{array}{l}\text { Farmer } \\
\text { Student } \\
\text { Private employee } \\
\text { Government employee } \\
\text { Merchant } \\
\text { Others }\end{array}$ & $\begin{array}{c}18 \\
8 \\
310 \\
232 \\
88 \\
67\end{array}$ & $\begin{array}{c}2.49 \\
1.11 \\
42.88 \\
32.09 \\
12.17 \\
9.27\end{array}$ \\
\hline
\end{tabular}


than $100 \mathrm{~m}$ from heavy traffic, and living less than $100 \mathrm{~m}$ from unpaved roads/streets were significantly associated with underfive children's respiratory symptoms.

Among children of under-five years, those children whose mother had a problem of uterine overstimulation at the time of their pregnancy were 2.20 at times heightened risk of suffering from respiratory symptoms as compared to their counterparts [AOR $=2.20$ at $95 \% \mathrm{CI}:(1.25-2.89)]$. Children from a mother who had done a regular exercise during their pregnancy period had a $40 \%$ lesser likelihood of developing respiratory symptoms than children whose mothers had been sedentary during pregnancy $[\mathrm{AOR}=0.60$ at $95 \% \mathrm{CI}:(0.41-0.89)]$. The adjusted odds of respiratory symptoms were 1.89 times higher among under-five children whose mothers had a hereditary respiratory disease when compared with their counterparts $[\mathrm{AOR}=1.89$ at $95 \% \mathrm{CI}$ : $(1.11$ -

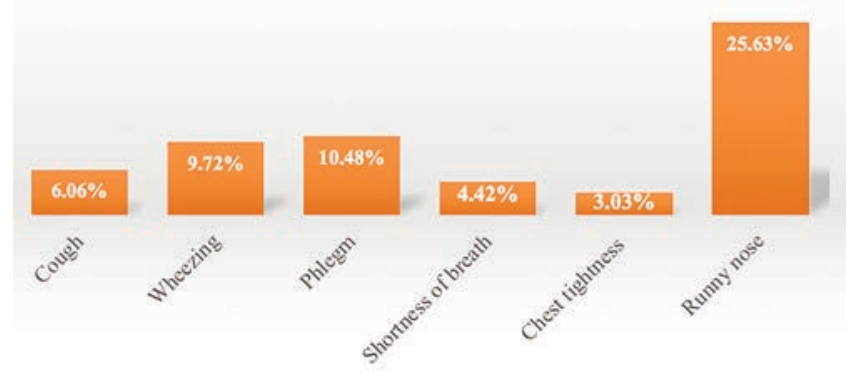

Figure 1. Prevalence of respiratory symptoms among under-five children in Gondar city, Northwest Ethiopia, 2019.

Table 2. Household air quality and housing characteristics of the study participants in Gondar city, Northwest Ethiopia, 2019.

\section{Variables}

Types of fuel usually used for cooking

Types of fuel usually used for heating

History of contact with farm animals

Cigarettes smoking (mothers/guardians)

Cockroach infestation in household

Painting/staining done in the last 6 months

Presence of new carpets, in the last 6 months

Using air fresheners

Presence of a kitchen exhaust fan

A pesticide application

Floor construction materials

Wall surface water-based paint

Ceiling surface $(\mathrm{n}=749)$

\section{Frequency $(\mathrm{n}=792)$}

\section{$\%$}

\section{Charcoal}

Electricity

Open fires

None

Wood, coal

Electricity

Yes

Yes

Yes

Yes

Yes

Yes

Yes

Yes

Wood and mud

Brick and concretel

Yes

Wooden

Painted

Cement

\section{Damp stains}

Yes

Visible mould

Yes

Place of cooking $(n=775)$

Open doors during cooking $(\mathrm{n}=680)$

Open windows during cooking ( $\mathrm{n}=676$ )

Length of time spend indoors on an average day

\begin{tabular}{|c|c|}
\hline & $\begin{array}{l}6 \text { to } 11 \text { hours } \\
11 \text { to } 15 \text { hours } \\
>15 \text { hours }\end{array}$ \\
\hline Presence of attached garage within $100 \mathrm{~m}$ of household & Yes \\
\hline Frequency of trucks passing through the nearby street & $\begin{array}{l}\text { Never } \\
\text { Seldom } \\
\text { Frequently } \\
\text { Almost the whole day }\end{array}$ \\
\hline Living in less than $100 \mathrm{~m}$ heavy traffic & Yes \\
\hline Living in less than $100 \mathrm{~m}$ (unpaved roads/streets) & Yes \\
\hline Exposure to animal allergens in early childhood & Yes \\
\hline Exposure to animal allergens in the present time & Yes \\
\hline
\end{tabular}

$479-60.48$

$273 \quad 34.47$

$40 \quad 5.05$

$341 \quad 43.06$

$440 \quad 55.56$

$11 \quad 1.39$

$47-5.93$

$24 \quad 3.03$

$379-47.85$

$110 \quad 13.89$

$110 \quad 13.89$

$48 \quad 6.06$

$40 \quad 5.05$

$157 \quad 19.82$

$542 \quad 68.43$

$250 \quad 31.57$

$174 \quad 21.97$

$576 \quad 76.90$

$131 \quad 17.49$

$42 \quad 5.61$

$63 \quad 7.95$

$67 \quad 8.46$

Inside $\quad 461 \quad 59.48$

$\begin{array}{lll}\text { Outside } & 314 & 40.52\end{array}$

Yes $241 \quad 35.44$

Yes $\quad 214 \quad 31.66$

$<6$ hours $\quad 198 \quad 25.00$

$250 \quad 31.57$

$165 \quad 20.83$

\begin{tabular}{l}
$179-22.60$ \\
\hline
\end{tabular}

$46-5.81$

$397-50.13$

$254 \quad 32.07$

$93-11.74$

$\begin{array}{cc}93 \\ 48 & 6.06\end{array}$

$162 \quad 20.45$

$\begin{array}{ll}102 & 20.45 \\ 194 & 24.49\end{array}$

$38 \quad 4.80$

$\begin{array}{ll}38 & 4.80 \\ 45 & 5.68\end{array}$


3.23)]. When compared to children whose parents did not use wood and coal, those who used wood and coal for heating indoors during humid weather conditions were 2.42 times more likely to develop respiratory symptoms $[\mathrm{AOR}=2.42$ at $95 \% \mathrm{CI}$ : (1.653.53)]. Children living in households infested by cockroaches were 1.95 times more likely to suffer from respiratory symptoms when compared with their counterparts [AOR $=1.95$ at 95\% CI: (1.362.90)]. Children whose parents used new carpets in HH were 2.38 times more likely to suffer from respiratory symptoms compared with their counterparts $[\mathrm{AOR}=2.38$ at $95 \% \mathrm{CI}$ : $(1.33-4.29)]$. Children living in a damp house were 1.66 times more likely to suffer from respiratory symptoms when compared with their counterparts $[\mathrm{AOR}=1.66$ at $95 \% \mathrm{CI}$ : (1.02-2.69)]. In households where windows were open at the time of cooking, the risk of experiencing respiratory symptoms among under-five children was $42 \%$ times less likely as compared to those households which remained closed during cooking time $\left[\mathrm{AOR}=0.58\right.$ at $95 \% \mathrm{CI}$ : $\left(\begin{array}{lll}0.36 & 0.93)\end{array}\right)$. Children living less than $100 \mathrm{~m}$ from heavy traffic areas were 1.94 times more likely to suffer from respiratory symptoms [AOR $=1.94$ at 95\% CI: (1.16-3.27)]. Children living less than $100 \mathrm{~m}$ from unpaved roads/streets were 2.89 times more likely to develop respiratory symptoms when compared with their counterparts [AOR $=2.89$ at $95 \% \mathrm{CI}:(1.89-4.55)]$ (Table 3$)$.

\section{Discussion}

This study found that a number of housing characteristics, indoor air pollution, and outdoor air pollution significantly contributed to an increase in the prevalence of respiratory symptoms among under-five children. In this study, we have found that the overall prevalence of respiratory symptoms among under-five children was $37.5 \%$ at $[95 \%$ (CI: 34.3-41)], of these (runny nose (25.63\%), phlegm (10.48\%), and wheezing (9.72 were commonly reported respiratory symptoms. This finding [37.5\%] was higher compared with previous studies in Ethiopia [20], India [15,21], Nepal [22], and Bangladesh [17]. The possible explanation could be the variation of the study setting, in which some of the studies were institutional-based, whereas our study was community-based, the study period, and the variability in socio-economic, housing, and environmental inequalities.

In regard to the independent factors affecting the respiratory symptoms among children of under-five years, those children whose mother had a problem of uterine overstimulation at the time of their pregnancy were 2.20 times at heightened risk of suffering from respiratory symptoms as compared to their counterparts. This finding may be related to the fact that whenever there is uterine overstimulation, the spiral artery which is responsible for supplying blood to the uterus tends to be ligated/ tied off and this leads the fetus to develop asphyxia due to uteroplacental insufficiency. Birth asphyxia has numerous long term impacts on the baby till childhood including multiple organ damage involving lungs and poor brain stem reflexes like breathing problems which finally pose children at a greater risk of experiencing respiratory symptoms [23].

Regular exercise during pregnancy was another determinant of under-five respiratory symptoms. Accordingly, children from mothers who had done a regular exercise during their pregnancy period had a $40 \%$ lesser likelihood of developing respiratory symptoms than children whose mothers had been sedentary during pregnancy. This could probably be explained by well-documented evidence that reports the benefits of exercise during pregnancy for the mother and the fetus with benefits persisting for the child into adulthood. Regular exercise during pregnancy decreases the risk of disease for children including respiratory symptoms in that the babies' hearts most likely had sped up and synchronized with their mothers' during exercise, allowing children to enjoy the same heart benefits, thereby having better-conditioned cardiac muscles which in turn mitigating their risk of respiratory symptoms [24,25]. The adjusted odds of respiratory symptoms were 1.98 times higher among under-five children whose mothers had hereditary respiratory disease. Infection and genetic factors affect the development of the lungs, either directly or indirectly, which can cause respiratory symptoms [26].

When comparing children whose parents did not use wood and coal, those who used wood and coal for heating indoors during humid weather conditions were 2.42 times more likely to develop respiratory symptoms. Evidence has shown that respiratory symptoms are a common problem with wood smoke exposure [27]. Studies suggest that wood smoke particles cause harm to human health through oxidative stress, cell toxicity, defects in cell regeneration, resulting in lung damage, and genotoxicity [28,29]. Children living in households infested by cockroaches were 1.95 times more likely to suffer from respiratory symptoms when compared with their counterparts. Cockroach exposure has been linked to cockroach sensitization and allergic respiratory symptoms [30]. Exposure to cockroaches can increase the risk for frequent wheezing of children with allergic or asthmatic parents in the first year of life even if cockroach infestation is not clear and a relatively low concentration is measured. While the cockroaches in the kitchen are most abundant, their presence in the bedroom and the living room may be more important for the induction of repeated wheeze in infancy [31]. Research in Ethiopia demonstrated that cockroaches are the potential source of multiresistant strains of bacterial pathogens and they are carriers of Klebsiella pneumonia [32]. This might enlighten the enhanced associations of respiratory symptoms with a cockroach infestation.

Under-five children whose parents used new carpets at home were 2.38 times more likely to suffer from respiratory symptoms compared with their counterparts. A possible explanation could be that a new carpet can be a source of chemical emissions. In addition to the carpet, the padding and adhesives all emit volatile organic compounds and some people report symptoms such as upper respiratory irritations, skin rash, shortness of breath, cough, and fatigue, which they associate with the new carpet installation, and the distinct odor of new carpet is usually attributed to the chemicals 4-phenyl cyclohexane (4-PC) [33]. Children living in a damp house were 1.66 more likely to suffer from respiratory symptoms. This study confirms previously-reported associations between a damp stain and current respiratory symptoms in children [34,35]. Damp living conditions have adversely affected children's respiratory health. Since both fungi and household dust mites thrive in humid environments, an allergic reaction to one or both of these allergens is suggested as a significant contributing factor in the development of more respiratory symptoms among children living in humid homes [36]. In households where windows were open at the time of cooking, the risk of experiencing respiratory symptoms among under-five children was $42 \%$ times less likely as compared to those households which remained closed during cooking time. Similar findings were reported to support this result [37,38]. Although most households reported opening windows during cooking, this study was conducted during winter and spring seasons. The ventilation level will likely decrease over the summer season as windows are often kept closed to minimize energy loss, which can contribute to higher summer indoor air pollutants than those found in this report [39]. Children living less than $100 \mathrm{~m}$ from heavy traffic were 1.94 times more likely to suffer from respiratory symptoms. Moving traffic is highly associated with higher emissions of organic carbon, elemental carbon, carbon monoxide, nitric oxide, hydrocarbons, and soot. This might explain the fact 
that emission of high proportions of diesel particles and other primary pollutants may enhance the associations of respiratory symptoms among under-five children living within $100 \mathrm{~m}$ of heavy traffic [40-43].

In the current study, children living less than $100 \mathrm{~m}$ from unpaved roads/streets were 2.89 times more likely to develop respiratory symptoms when compared with children living more than
$100 \mathrm{~m}$. Unpaved roads/streets may increase the particulate matter concentration and airborne dust [44], which in turn are responsible for multiplying effects on respiratory symptoms accounted for children living in the proximity of unpaved roads or streets [45].

\section{Limitations of the study}

Even though a large sample size and random sampling tech-

Table 3. Factors associated with children respiratory symptoms in Gondar city, Northwest Ethiopia, 2019.

\begin{tabular}{|c|c|c|c|c|c|}
\hline Variables & & $\begin{array}{r}\text { Respirator } \\
\text { Absent }\end{array}$ & mptom & COR 95\% CI & AOR 95\% CI \\
\hline Age of child & $\begin{array}{l}12 \text { months } \\
\text { 13-24 months } \\
\text { 25-36 months } \\
\text { 37-48 months } \\
\text { 49-59 months }\end{array}$ & $\begin{array}{c}135 \\
134 \\
101 \\
98 \\
27\end{array}$ & $\begin{array}{l}69 \\
79 \\
80 \\
54 \\
15\end{array}$ & $\begin{array}{c}1 \\
1.15(0.77-1.72) \\
1.55(1.03-2.34)^{*} \\
1.07(0.69-1.68) \\
1.09(0.54-2.17)\end{array}$ & $\begin{array}{c}1 \\
0.82(0.49-1.35) \\
1.47(0.85-2.38) \\
0.84(0.49-1.44) \\
1.09(0.48-2.49)\end{array}$ \\
\hline Marital status & $\begin{array}{l}\text { Married } \\
\text { Unmarried }\end{array}$ & $\begin{array}{c}438 \\
57\end{array}$ & $\begin{array}{c}246 \\
51\end{array}$ & $\begin{array}{c}1 \\
1.59(1.06-2.39)\end{array}$ & $\begin{array}{c}1 \\
1.18(0.72-2.49)\end{array}$ \\
\hline Hyperirritability of uterus during pregnancy & $\begin{array}{l}\text { No } \\
\text { Yes }\end{array}$ & $\begin{array}{l}448 \\
36\end{array}$ & $\begin{array}{c}235 \\
54\end{array}$ & $\begin{array}{c}1 \\
2.86(1.8-4.48)\end{array}$ & $2.20(1.25-2.89)^{*}$ \\
\hline Regular physical activity during pregnancy & $\begin{array}{l}\text { No } \\
\text { Yes }\end{array}$ & $\begin{array}{l}194 \\
293\end{array}$ & $\begin{array}{l}163 \\
129\end{array}$ & $\begin{array}{c}1 \\
0.52(0.39-0.70)\end{array}$ & $\begin{array}{c}1 \\
0.60(0.41-0.89)^{*}\end{array}$ \\
\hline Stress perception of mother during pregnancy & $\begin{array}{l}\text { No } \\
\text { Yes }\end{array}$ & $\begin{array}{c}441 \\
42\end{array}$ & $\begin{array}{c}249 \\
41\end{array}$ & $\begin{array}{c}1 \\
1.73(1.09-2.73)\end{array}$ & $\begin{array}{c}1 \\
1.14(0.62-2.08)\end{array}$ \\
\hline Heredity of a respiratory disease & $\begin{array}{l}\text { No } \\
\text { Yes }\end{array}$ & $\begin{array}{c}447 \\
45\end{array}$ & $\begin{array}{c}247 \\
50\end{array}$ & $\begin{array}{c}1 \\
2.01(1.30-3.09)\end{array}$ & $\begin{array}{c}1 \\
1.89(1.11-3.23)^{*}\end{array}$ \\
\hline Fuel is usually used for heating & $\begin{array}{l}\text { None } \\
\text { Wood and coal } \\
\text { Electricity }\end{array}$ & $\begin{array}{c}250 \\
238 \\
7\end{array}$ & $\begin{array}{c}91 \\
202 \\
4\end{array}$ & $\begin{array}{c}1 \\
2.33(1.72-3.16)^{*} \\
1.57(0.45-5.48)\end{array}$ & $\begin{array}{c}1 \\
2.42(1.65-3.53)^{* *} \\
1.45(0.31-6.70)\end{array}$ \\
\hline $\begin{array}{l}\text { History of contact with farm animals while being } \\
\text { pregnant with this child }\end{array}$ & $\begin{array}{l}\text { No } \\
\text { Yes }\end{array}$ & $\begin{array}{c}473 \\
22 \\
\end{array}$ & $\begin{array}{r}272 \\
25\end{array}$ & $\begin{array}{c}1 \\
1.97(1.09-3.57)\end{array}$ & $\begin{array}{c}1 \\
1.43(0.68-3.01)\end{array}$ \\
\hline Cockroach infestation in $\mathrm{HH}$ & $\begin{array}{l}\text { No } \\
\text { Yes }\end{array}$ & $\begin{array}{l}284 \\
211\end{array}$ & $\begin{array}{l}129 \\
168\end{array}$ & $\begin{array}{c}1 \\
1.75(1.31-2.34)\end{array}$ & $\begin{array}{c}1 \\
1.95(1.36-2.90)^{* *}\end{array}$ \\
\hline Painting/staining been done in the last 6 months $\mathrm{HH}$ & $\begin{array}{l}\text { No } \\
\text { Yes }\end{array}$ & $\begin{array}{r}440 \\
55\end{array}$ & $\begin{array}{c}242 \\
55 \\
\end{array}$ & $\begin{array}{c}1 \\
1.82(1.21-2.73)\end{array}$ & $\begin{array}{c}1 \\
0.52(0.17-1.61)\end{array}$ \\
\hline New carpets, drapes or other textiles HH & $\begin{array}{l}\text { No } \\
\text { Yes }\end{array}$ & $\begin{array}{c}451 \\
44\end{array}$ & $\begin{array}{c}231 \\
66\end{array}$ & $\begin{array}{c}1 \\
2.93(1.934-4.43)\end{array}$ & $\begin{array}{c}1 \\
2.38(1.33-4.29)^{*}\end{array}$ \\
\hline Pesticide application at $\mathrm{HH}$ & $\begin{array}{l}\text { No } \\
\text { Yes }\end{array}$ & $\begin{array}{c}416 \\
79\end{array}$ & $\begin{array}{c}219 \\
78\end{array}$ & $\begin{array}{c}1 \\
1.88(1.32-2.67)\end{array}$ & $\begin{array}{c}1 \\
2.64(1.47-4.74) \\
\end{array}$ \\
\hline+2 & $\begin{array}{l}\text { No } \\
\text { Yes }\end{array}$ & $\begin{array}{l}463 \\
32\end{array}$ & $\begin{array}{r}266 \\
31\end{array}$ & $\begin{array}{c}1 \\
1.69(1.006-2.82)\end{array}$ & $\begin{array}{c}1 \\
1.66(1.02-2.69)^{*}\end{array}$ \\
\hline Open windows during cooking & $\begin{array}{l}\text { No } \\
\text { Yes }\end{array}$ & $\begin{array}{l}271 \\
143\end{array}$ & $\begin{array}{c}191 \\
71\end{array}$ & $\begin{array}{c}1 \\
0.70(0.50-0.99)\end{array}$ & $\begin{array}{c}1 \\
0.58(0.36-0.93)^{*}\end{array}$ \\
\hline Poor outdoor air influence during cooking & $\begin{array}{l}\text { No } \\
\text { Yes }\end{array}$ & $\begin{array}{c}371 \\
50\end{array}$ & $\begin{array}{c}207 \\
55\end{array}$ & $\begin{array}{c}1 \\
1.97(1.29-2.99)\end{array}$ & $\begin{array}{c}1 \\
1.23(0.56-2.72)\end{array}$ \\
\hline Frequency of trucks passing through the nearby street & $\begin{array}{l}\text { Never } \\
\text { Seldom } \\
\text { Frequently } \\
\text { Whole day }\end{array}$ & $\begin{array}{l}274 \\
138 \\
57 \\
26\end{array}$ & $\begin{array}{l}123 \\
116 \\
36 \\
22\end{array}$ & $\begin{array}{c}1 \\
1.87(1.35-2.59)^{*} \\
1.40(0.88-2.24) \\
1.88(1.02-3.46)^{*}\end{array}$ & $\begin{array}{c}1 \\
1.25(0.79-1.96) \\
0.67(0.36-1.25) \\
0.79(0.34-1.79)\end{array}$ \\
\hline Living less than $100 \mathrm{~m}$ from heavy traffic & $\begin{array}{l}\text { No } \\
\text { Yes }\end{array}$ & $\begin{array}{c}422 \\
73\end{array}$ & $\begin{array}{c}208 \\
89\end{array}$ & $\begin{array}{c}1 \\
2.47(1.74-3.51)\end{array}$ & $1.94(1.16-3.27)^{*}$ \\
\hline Living less than $100 \mathrm{~m}$ from unpaved roads/streets & $\begin{array}{l}\text { No } \\
\text { Yes }\end{array}$ & $\begin{array}{c}424 \\
71\end{array}$ & $\begin{array}{l}174 \\
123 \\
\end{array}$ & $4.22(3.00-5.94)$ & $\begin{array}{c}1 \\
2.89(1.89-4.55)^{* *}\end{array}$ \\
\hline Exposure to animal allergens in early childhood & $\begin{array}{l}\text { No } \\
\text { Yes }\end{array}$ & $\begin{array}{c}481 \\
14\end{array}$ & $\begin{array}{c}273 \\
24\end{array}$ & $\begin{array}{c}1 \\
3.02(1.54-5.94)\end{array}$ & $\begin{array}{c}1 \\
2.12(0.54-8.40)\end{array}$ \\
\hline Exposure to animal allergens in the present time & $\begin{array}{l}\text { No } \\
\text { Yes }\end{array}$ & $\begin{array}{c}477 \\
18\end{array}$ & $\begin{array}{c}270 \\
27\end{array}$ & $\begin{array}{c}1 \\
2.65 \mathrm{l}(1.43-4.90)\end{array}$ & $\begin{array}{c}1 \\
0.74(0.21-2.69)\end{array}$ \\
\hline
\end{tabular}

COR, crude odds ratio; AOR, adjusted odds ratio; $\mathrm{HH}$, household; 1 , reference group; ${ }^{*} \mathrm{p}<0.05,{ }^{*} * \mathrm{p}<0.001$. 
nique employed in this study help for greater generalizability, the lack of measurements i.e. pulmonary function test was one of the limitations. Furthermore, recall bias and social desirability biases might be high in such types of self-reported cross-sectional studies.

\section{Conclusions}

In this study, the overall prevalence of respiratory symptoms among under-five children was relatively high. Personal and environmental characteristics influencing symptom occurrence were identified. Respiratory symptoms will be minimized by reducing exposure to indoor and outdoor air pollution and enhancing housing characteristics.

\section{Acknowledgments}

We are very indebted to Gondar City Health Office for permitting to conduct the study and providing the necessary preliminary information while conducting this study. We do wish to extend our gratitude to the study participants, supervisors, and data collectors.

\section{Abbreviations}

ALRIs: acute lower respiratory infections;

AOR: adjusted odds ratio;

ARI: acute respiratory infections;

COR: crude odds ratio;

HH: household;

OR: odd ratio;

SSA: sub-Saharan African.

\section{References}

1. Rudan I, Tomaskovic L, Boschi-Pinto C, Campbell H. Global estimate of the incidence of clinical pneumonia among children under five years of age. Bull World Health Organ 2004;82:895-903.

2. Leowski J. Mortality from acute respiratory infections in children under 5 years of age: global estimates. World Health Stat Q 1986;39:138-44.

3. Adesanya OA, Darboe A, Rojas BM, Abiodun DE, Beogo I. Factors contributing to regional inequalities in acute respiratory infections symptoms among under-five children in Nigeria: a decomposition analysis. Int J Equity Health 2017;16:140.

4. Accinelli RA, Leon-Abarca JA, Gozal D. Ecological study on solid fuel use and pneumonia in young children: A worldwide association. Respirology 2017;22:149-56.

5. Ramani VK, Pattankar J, Puttahonnappa SK. Acute respiratory infections among under-five age group children at urban slums of gulbarga city: A longitudinal study. J Clin Diagn Res 2016;10:LC08.

6. Seidu AA, Dickson KS, Ahinkorah BO, Amu H, Darteh EKM, Kumi-Kyereme A. Prevalence and determinants of acute lower respiratory infections among children under-five years in subSaharan Africa: evidence from demographic and health surveys. SSM Popul Health 2019;8:100443.

7. Nandasena S, Wickremasinghe AR, Sathiakumar N. Indoor air pollution and respiratory health of children in the developing world. World J Clin Pediatr 2013;2:6.

8. Akinyemi JO, Morakinyo OM. Household environment and symptoms of childhood acute respiratory tract infections in Nigeria, 2003-2013: a decade of progress and stagnation. BMC Infect Dis 2018;18:296.

9. Quintussi M, Van de Poel E, Panda P, Rutten F. Economic consequences of ill-health for households in northern rural India. BMC Health Serv Res 2015;15:179.

10. Miller NP, Amouzou A, Tafesse M, Hazel E, Legesse H, Degefie $T$, et al. Integrated community case management of childhood illness in Ethiopia: implementation strength and quality of care. Am J Trop Med Hyg 2014;91:424-34.

11. Kolawole O, Oguntoye M, Dam T, Chunara R. Etiology of respiratory tract infections in the community and clinic in Ilorin, Nigeria. BMC Rese Notes 2017;10:712.

12. Ujunwa F, Ezeonu C. Risk Factors for acute respiratory tract infections in under-five children in Enugu Southeast Nigeria. Ann Med Health Sci Res 2014;4:95-9.

13. Arifin WN. Introduction to sample size calculation. Educ Med J 2013;5:130.

14. Woldeamanuel BT, Gebreyesus HL. Prevalence and risk factors for chest-related symptoms of acute respiratory tract infections among under five children: Case of Ethiopia. J Tre Bio Res 2019;2:1-7.

15. Sharma D, Kuppusamy K, Bhoorasamy A. Prevalence of acute respiratory infections (ARI) and their determinants in under five children in urban and rural areas of Kancheepuram district, South India. Ann Trop Med Public Health 2013;6:513.

16. Yousef FM, Hamed AF. Prevalence of acute respiratory infection and related risk factors in school-age children in Egypt: a cross-sectional study. Int J Curr Res Med Sci 2016;2:50-8.

17. Hasan M, Tasfina S, Haque SR, Saif-Ur-Rahman K, Khalequzzaman M, Bari W, et al. Association of biomass fuel smoke with respiratory symptoms among children under 5 years of age in urban areas: results from Bangladesh Urban Health Survey, 2013. Environ Health Prev Med 2019;24:65.

18. Benefits Bridge. United Concordia [Internet]. 6 common respiratory disease symptoms to be aware of. 2019. Accessed on: 8 February 2019. Available from: https://benefitsbridge.unitedconcordia.com/6-common-respiratory-disease-symptoms-tobe-aware-of/

19. Mickey RM, Greenland S. The impact of confounder selection criteria on effect estimation. Am J Epidemiol 1989;129:12537.

20. Dagne H, Andualem Z, Dagnew B, Taddese AA. Acute respiratory infection and its associated factors among children under-five years attending pediatrics ward at University of Gondar Comprehensive Specialized Hospital, Northwest Ethiopia: institution-based cross-sectional study. BMC Pediatr 2020;20:1-7.

21. Savitha AK, Gopalakrishnan S. Determinants of acute respiratory infections among under five children in a rural area of Tamil Nadu, India. J Family Med Prim Care 2018;7:1268-73.

22. Maharjan PL, Sharma Y. Prevalence and determinants of acute respiratory infection among children under age five in Gorkha Municipality, Gorkha. Glob J Pharmaceu Sci 2017;2:555588.

23. Nagdyman N, Kömen W, Ko HK, Müller C, Obladen M. Early biochemical indicators of hypoxic-ischemic encephalopathy after birth asphyxia. Pediatr Res 2001;49:502-6.

24. Moyer C, Reoyo OR, May L. The influence of prenatal exercise on offspring health: A review. Clin Med Insights Womens Health 2016;9:37-42.

25. The New Work Times [Internet]. Exercise during pregnancy may have lasting benefits for babies (G. Reynolds). 2019. Accessed on: 19 August 2019. Available from: https:/www.nytimes.com/2019/08/07/well/move/exerciseduring-pregnancy-may-have-lasting-benefits-for-babies.html

26. National Center for Biotechnology Information (US). Genes 
and Disease [Internet]. 1998. Accessed on: 15 March 2020. Available from: https://www.ncbi.nlm.nih.gov/books/ NBK22167/

27. Triche EW, Belanger K, Beckett W, Bracken MB, Holford TR, Gent $\mathrm{J}$, et al. Infant respiratory symptoms associated with indoor heating sources. Am J Respir Crit Care Med 2002;166:1105-11.

28. WHO. Residential heating with wood and coal: health impacts and policy options in Europe and North America. 2015. Avilable from: https://www.euro.who.int/_data/assets/pdf_ file/0009/271836/ResidentialHeatingWoodCoalHealthImpacts .pdf

29. Riddervold I, Bønløkke J, Olin AC, Grønborg T, Schlünssen V, Louring-Skogstrand K, et al. Effects of wood smoke particles from wood-burning stoves on the respiratory health of atopic humans. ParticFibre Toxicol 2012;9:12.

30. Do DC, Zhao Y, Gao P. Cockroach allergen exposure and risk of asthma. Allergy 2016;71:463-74.

31. Gold DR, Burge HA, Carey V, Milton DK, Platts-Mills T, Weiss ST. Predictors of repeated wheeze in the first year of life: the relative roles of cockroach, birth weight, acute lower respiratory illness, and maternal smoking. Am J Respir Critic Care Med 1999;160:227-36.

32. Moges F, Eshetie S, Endris M, Huruy K, Muluye D, Feleke T, et al. Cockroaches as a source of high bacterial pathogens with multidrug resistant strains in Gondar town, Ethiopia. BioMed Res Int 2016;2016:2825056.

33. MedicineNet [Internet]. New carpet allergy. 2017. Accessed on: 15 March 2020. Available from: https://www.medicinenet.com $/ \mathrm{script} / \mathrm{main} /$ art.asp? articlekey $=21803$

34. WHO. Report of the International Conference on Environmental threats to the health of children: Hazards and vulnerability, Bangkok, 3-7 March 2002. Genwva: World Health Organization; 2002.

35. Garrett MH, Rayment PR, Hooper MA, Abramson MJ, Hooper BM. Indoor airborne fungal spores, house dampness and associations with environmental factors and respiratory health in children. Clin Exp Allergy 1998;28:459-67.

36. Li CS, Hsu LY. Home dampness and childhood respiratory symptoms in a subtropical climate. Arch Environ Health 1996;51:42-6.

37. Abuka T. Prevalence of pneumonia and associated factors among children 2-59 months old in Wondo Genet district, Sidama zone, SNNPR, Ethiopia. Curr Pediatr Res 2017;21.

38. Fekadu GA, Terefe MW, Alemie GA. Prevalence of pneumonia among under-five children in Este Town and the surrounding rural Kebeles, Northwest Ethiopia: a community based cross sectional study. Sci J Public Health 2014;2:150-5.

39. Rumchev K, Spickett J, Brown H, Mkhweli B. Indoor air pollution from biomass combustion and respiratory symptoms of women and children in a Zimbabwean village. Indoor Air 2008; $17: 468-74$.

40. Shah SD, Cocker DR, Miller JW, Norbeck JM. Emission rates of particulate matter and elemental and organic carbon from in-use diesel engines. Environ Sci Technol 2004;38:2544-50.

41. Tong H, Hung W, Cheung C. On-road motor vehicle emissions and fuel consumption in urban driving conditions. J Air Waste Manage Assoc 2000;50:543-54.

42. Ryan PH, LeMasters G, Biagini J, Bernstein D, Grinshpun $\mathrm{SA}$, Shukla $\mathrm{R}$, et al. Is it traffic type, volume, or distance? Wheezing in infants living near truck and bus traffic. J Allergy Clin Immunol 2005;116:279-84.

43. Garshick E, Laden F, Hart JE, Caron A. Residence near a major road and respiratory symptoms in U.S. veterans. Epidemiology 2003;14:728-36.

44. Khan RK, Strand MA. Road dust and its effect on human health: a literature review. Epidemiol Health 2018;40:e2018013.

45. Sarmiento-Suárez R, Medina K. Prevalence of respiratory symptoms associated with outdoor and indoor air pollution in Bogota 2012. WIT Transactions on the built environment. 2013;134:713-24

Received for publication: 6 May 2020. Accepted for publication: 10 August 2020.

This work is licensed under a Creative Commons Attribution-NonCommercial 4.0 International License (CC BY-NC 4.0).

CCopyright: the Author(s), 2020

Licensee PAGEPress, Italy

Multidisciplinary Respiratory Medicine 2020; 15:685

doi:10.4081/mrm.2020.685 